\title{
Mutual Relationship between Tau and Central Insulin Signalling: Consequences for AD and Tauopathies?
}

\author{
Maud Gratuze $^{a}$ Aurélie Joly-Amado ${ }^{b}$ Didier Vieau ${ }^{c}$ Luc Buée $^{c}$ David Blum ${ }^{c}$ \\ ${ }^{a}$ Centre de Recherche du Centre Hospitalier de I'Université Laval de Québec, Axe Neurosciences, Université \\ Laval, Québec, QC, Canada; ${ }^{b}$ Byrd Alzheimer's Institute, Department of Molecular Pharmacology and Physiology, \\ University of South Florida, Tampa, FL, USA; ' ${ }^{C}$ nniversité de Lille, Inserm, CHU Lille, UMR-S 1172 - JPArc, \\ "Alzheimer and Tauopathies," Lille, France
}

\section{Keywords}

Alzheimer disease · Tauopathy · Tau · Brain insulin signalling $\cdot$ Metabolic disorders

\begin{abstract}
Alzheimer disease (AD) is a progressive neurodegenerative disorder mainly characterized by cognitive deficits and neuropathological changes such as Tau lesions and amyloid plaques, but also associated with non-cognitive symptomatology. Metabolic and neuroendocrine abnormalities, such as alterations in body weight, brain insulin impairments, and lower brain glucose metabolism, which often precede clinical diagnosis, have been extensively reported in AD patients. However, the origin of these symptoms and their relation to pathology and cognitive impairments remain misunderstood. Insulin is a hormone involved in the control of energy homeostasis both peripherally and centrally, and insulin-resistant state has been linked to increased risk of dementia. It is now well established that insulin resistance can exacerbate Tau lesions, mainly by disrupting the balance between Tau kinases and phosphatases. On the other hand, the emerging literature indicates that Tau protein can also mod-
\end{abstract}

ulate insulin signalling in the brain, thus creating a detrimental vicious circle. The following review will highlight our current understanding of the role of insulin in the brain and its relation to Tau protein in the context of $A D$ and tauopathies. Considering that insulin signalling is prone to be pharmacologically targeted at multiple levels, it constitutes an appealing approach to improve both insulin brain sensitivity and mitigate brain pathology with expected positive outcome in terms of cognition.

(c) 2018 S. Karger AG, Basel

\section{Central Insulin Signalling: Impact on Cognition and Metabolism}

Brain Insulin and Receptor

Insulin is a peptidic hormone containing two chains, discovered in 1921 by Banting and Best [1]. In peripheral tissues, insulin facilitates glucose utilization and suppresses hepatic glucose production. Interestingly, insulin

M.G. and A.J.-A. contributed equally to this review.

\section{KARGER}

(c) 2018 S. Karger AG, Basel

E-Mail karger@karger.com

www.karger.com/nen
David Blum

Inserm UMR-S 1172, "Alzheimer \& Tauopathies"

Place de Verdun

FR-59045, Lille Cedex (France)

E-Mail david.blum@inserm.fr 
was first detected in the rat brain through immunostaining in 1978 [2] in much higher concentration than in the plasma and seemed to be independent of the peripheral concentration [3]. Few years later, insulin mRNA was detected by in situ hybridization in various brain areas including hypothalamus, hippocampus, and olfactory bulb in rodents $[4,5]$, suggesting that the central nervous system might be able to produce the hormone. While central insulin production is still controversial, insulin transport from the periphery to the brain is well documented. Physiological transport of insulin through the blood brain barrier $(\mathrm{BBB})$ was first reported in rabbits using radiolabeled insulin [6]. Immunoreactive insulin was also found in dog's brain and seemed to be correlated with basal plasma levels [7] and dependent on feeding state, being lower during fasting [8]. Insulin transport requires binding to the insulin receptor (IR) and transcytosis of the IR insulin complex through brain endothelial cells. Interestingly, this transport can be modulated, for instance by high-fat diet, astrocyte stimulation, or nitric oxide inhibition [9].

IR is a heterotetrameric membrane glycoprotein belonging to the tyrosine kinase receptor family which is composed of two $\alpha$ - and two $\beta$-subunits. IR is widely expressed in peripheral tissues, and radiolabeled ${ }^{125} \mathrm{I}$-insulin allowed the detection of the receptor in the brain of monkeys, pigeons, humans and rats [10-12]. IRs found in the brain and liver showed different patterns of migration during electrophoresis, suggesting 2 different isoforms [13]. In addition, in contrast to peripheral IRs, brain receptors are not downregulated by insulin excess [14]. Brain IR is present at all stages of development, although its distribution and concentration vary between embryonic and adult brain, consistent with the role of insulin in neurogenesis [12]. In situ hybridization of IR mRNA in the adult rat brain revealed high gene expression in the hypothalamus, more particularly in the anterior nuclei, in the hippocampus, olfactory bulbs, and the choroid plexus [15], regions concerned with olfaction, appetite, cognition, and autonomic functions [16].

As it does in the periphery, brain insulin signalling through its receptor involves the tyrosine phosphorylation of cellular substrates, including several IR substrates (IRSs) [17] as well as other scaffold proteins such as Srchomology collagen (Shc) $[18,19]$ and Grb2-associated docking protein (Grb2-SOS) [20]. The IRSs ensure metabolic effects of insulin through the activation of phosphatidylinositol 3-kinase (PI3K) which recruits both the Ser/ Thr 3-phosphatidylinositol-dependent protein kinase (PDK) and protein kinase $\mathrm{B}$ (PKB or Akt) to the plasma membrane, where Akt is activated by PDK1- and PDK2
[21] (Fig. 1). At the end of this pathway, mTOR links insulin signalling to nutrient sensing [22]. Mitogenic effects of insulin involve the recruitment of mitogen-activated protein kinases through small G-protein Ras leading to the translocation of ERK to the nucleus, where it controls gene expression [23].

\section{Role of Central Activation of IR on Metabolism}

The role of central IR activation in the regulation of glucose metabolism and feeding behavior is well described. For instance, study of the neuron-specific knockout mouse model of the IR (NIRKO mice) showed that neuronal inactivation of the IR in the central nervous system led to increased food intake and obesity, together with insulin resistance, hyperinsulinaemia, and hypertriglyceridaemia [24]. More particularly, the arcuate nucleus (ARC) of the hypothalamus plays a pivotal role in the metabolic action of insulin in the brain. In the ARC, two neuronal populations are antagonist in the regulation of food intake and energy expenditure: neurons producing pro-opiomelanocortin (POMC neurons) and neurons producing agouti-related protein (AgRP) and neuropeptide Y (NPY) (AgRP-neurons) which project to each other and to second-order neurons, in different hypothalamic areas (paraventricular nucleus, ventromedial hypothalamus...). POMC neurons decrease food intake and increase energy expenditure via the release of $\alpha$-melanocyte-stimulating hormone ( $\alpha-\mathrm{MSH})$ and through activation of melanocortin receptors (MCRs) $[25,26]$. AgRPneurons increase feeding by opposing the anorexigenic actions of the neighboring POMC neurons [27-29] through the release of AgRP, a competitive inhibitor of MCRs [26, 30]. Acute depletion of AgRP neurons leads to life-threatening anorexia [31-34]. IRs are highly expressed on the surface of both POMC and AgRP neurons $[35,36]$. Selective inactivation of IR in these neurons showed that AgRP neurons, rather than POMC neurons are required for central insulin control of hepatic glucose production [18]. In the same manner, inactivation of IRs in NPY-expressing neurons induced an obese phenotype, leading to the conclusion that insulin signalling in NPY neurons controls food intake and energy expenditure [37]. Furthermore, insulin decreases expression of the orexigenic peptides AgRP and NPY, leading to decreased food intake and increased expression of POMC [38], resulting in increased levels of a-MSH, which promotes anorexia and increases energy expenditure [39]. In addition to the hypothalamus, insulin signalling was also shown to play a role in reward dopaminergic circuitry, since inactivation of IR in tyrosine hydroxylase-expressing cells re- 


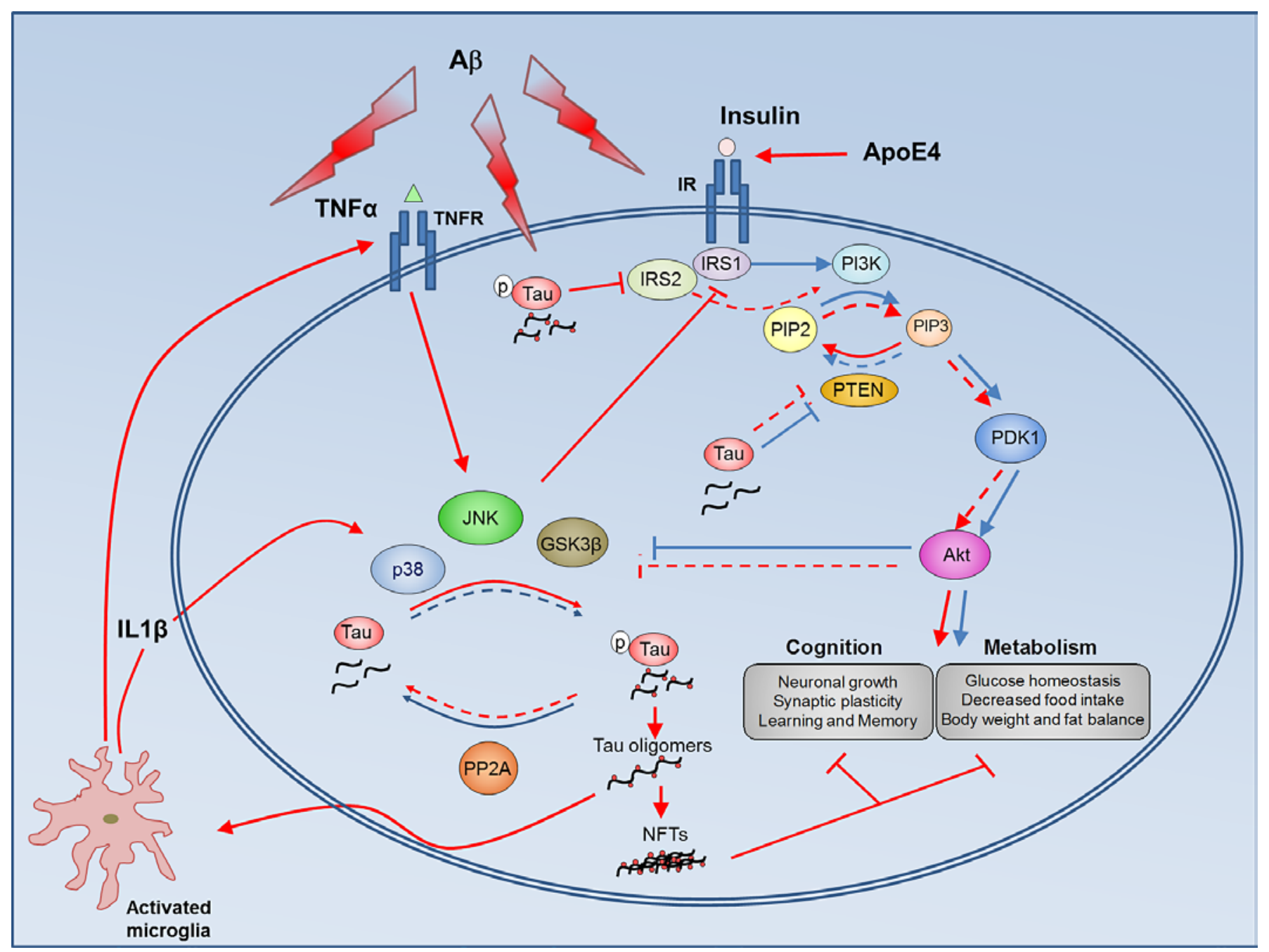

Fig. 1. Intracellular mechanisms linking insulin signalling, Tau, and $\mathrm{A} \beta$ pathology. Under physiological conditions (blue arrows), insulin binds to its receptor and induces phosphorylation and activation of the PDK1 and Akt pathway through PI3K, leading to increased cognition and metabolism regulation. Insulin beneficial effects on Tau protein involve inhibition of Tau kinases such as GSK3 $\beta$ and p38 by Akt, thus limiting Tau hyperphosphorylation. Monomers of Tau protein also contribute to normal insulin signalling by inhibiting the conversion of PIP3 back to PIP2 through PTEN. In Alzheimer's pathology (red arrows), a vicious circle between insulin resistance, Tau pathology and $A \beta$ pathology takes place. Insulin resistance leads to a decrease in Akt stimulation thus diminishing insulin action on cognition and metabolism. Reduction of Tau kinase inhibition leads to Tau hyperphosphorylation, aggregation in Tau oligomers and NFTs. Insulin resistance can be promoted by $\mathrm{A} \beta$ oligomers and ApoE 4 . A $\beta$ oligomers can contribute to insulin resistance by competitively binding and internalizing
IRs and by increasing the phosphorylation of IRS-1 and JNK. ApoE4 reduces insulin-IR interaction and impairs IR trafficking. Inflammation triggered by Tau and $\mathrm{A} \beta$ oligomers induces release of cytokines such as IL1 $\beta$ and TNF $\alpha$ by activated microglia which stimulate Tau kinases (JNK, p38), thus precipitating Tau pathology. Resulting NFTs then lead to cognitive impairments and metabolism dysregulation, which contribute to the propagation of $\mathrm{AD}$ pathogenesis. IR, insulin receptor; IRS-1/2, insulin receptor substrate 1/2; PI3K, phosphatidylinositol-3-kinases; PIP2, phosphatidylinositol 4,5-bisphosphate; PIP3, phosphatidylinositol $(3,4,5)$-trisphosphate; PTEN, phosphatase and tensin homolog; PDK1, 3-phosphoinositide-dependent protein kinase-1; Akt, protein kinase B; GSK3 $\beta$, glycogen synthase kinase 3 beta; JNK, c-Jun $\mathrm{N}$-terminal kinases; P38, p38 mitogen-activated protein kinases; PP2A, protein phosphatase 2; IL1 $\beta$, interleukin 1 beta; TNFa, tumor necrosis factor alpha; TNFR, tumor necrosis factor receptor; NFTs, neurofibrillary tangles. 
sulted in increased body weight, increased fat mass, and hyperphagia, and seemed to be dependent on dopaminergic neurons in the ventral tegmental area and substantia nigra [40].

Experiments using intranasal insulin, which allow the uptake of insulin from olfactory nerves [41], bypassing the $\mathrm{BBB}$, were of significant importance to isolate insulin effects on the brain from the periphery. In humans, intranasal insulin has been shown to regulate response to food cues and smelling capacity [42], to increase satiety [43], and to decrease food intake [44]. In animal models, brain insulin has been reported to be involved in satiety [45], reduction of lipolysis in adipose tissue [46], and regulation of insulin sensitivity in skeletal muscles and liver, where brain insulin is notably required for glucose production [47]. In the rat brain, insulin regulates enzymes of cerebral glucose metabolism such as hexokinase and phosphofructokinase [48]. Like at the periphery, insulin is involved in glucose uptake in the brain, although to a lesser extent since the most abundant glucose transporters in the brain, Glut-1 (entire brain, astrocytes, and endothelial cells), Glut-2 (hypothalamus), and Glut-3, (the major glucose transporter in the neurons of the cerebellum, striatum, cortex, and hippocampus and some glial and endothelial cells) are not insulin-dependent (reviewed in [49]). Indeed, insulin-dependent Glut-4 is found at much lower levels in selective areas of the brain, including the olfactory bulb, dentate gyrus of the hippocampus, hypothalamus, and cortex [50]. The neuron-specific glucose transporter Glut-8 (also known as Glutx1), also insulin-dependent, is expressed in several areas of the brain, in particular in the hippocampus where it is thought to contribute to glucose homeostasis in neurons $[51,52]$.

\section{Role of Central Activation of IR on Cognition}

The location of IR in regions involved with cognition such as the cortex and hippocampus suggests a role of the hormone beyond metabolism. Insulin, through Glut-4 and Glut-8, supports cognition by ensuring cognitive areas receive the necessary amount of fuel to function. Several studies in mice indicate that insulin contributes to changes in hippocampal synaptic plasticity by favouring long-term potentiation (LTP) [53] and long-term depression [54], two molecular mechanisms involved in hippocampal-dependent learning and memory. In accordance, impaired LTP and spatial learning deficits have been reported in mice with a downregulation of IRs in the hippocampus [55]. One of the underlying mechanisms is based on the regulation of $\mathrm{N}$-methyl-D-aspartate receptor membrane expression by insulin [56]. These changes are thought to involve insulin activation of ERK1/2 [57] or PI3K signalling [58]. Insulin signalling has also been shown to contribute to synaptogenesis and synaptic remodeling in the rat brain and cultured hippocampal neurons [59], two mechanisms essential for neuronal plasticity. Recently, an interesting study has shown that brain insulin-resistance induced by high-fat diet impairs memory and underlying synaptic plasticity through hyperpalmitoylation of AMPA glutamate receptor subunit GluA1 [60], indicating that intact insulin signalling is required for memory formation. Besides experimental models, in humans, intranasal insulin has been shown to improve memory functions in healthy subjects $[61,62]$, with no effect on word recall and non-declarative memory but rather on declarative, hippocampus-dependent memory contents $[62,63]$. Conversely, both type 1 and type 2 diabetic patients have been shown to exhibit cognitive impairments and an increased risk of Alzheimer disease (AD) [64] consistent with the above-mentioned idea that unfavourable metabolic conditions reduce insulin transport into the brain [9]. Considering the presumable role of insulin regarding brain glucose uptake, this also fits with the reduced brain glucose uptake associated with dementia [65].

\section{Overview on Tau and Tauopathies}

Since its discovery in 1975 [66], Tau protein became of great interest when it was identified as the main component of neurofibrillary tangles (NFTs) in the brains of patients with $\mathrm{AD}$ [67-69]. Tau protein is expressed mainly in the human brain as 6 isoforms, generated by alternative splicing $[70,71]$. Tau belongs to the microtubule-associated proteins (MAPs) family which includes MAP2 and MAP4 [72] and is well known for its role in microtubule assembly and stability, playing a role in diverse cellular processes such as cell morphogenesis, cell division, and intracellular trafficking. It is however now considered that, beyond microtubules, Tau exerts much larger neuronal functions, notably at the level of synapses and nuclei [73-75]. Tau is also physiologically released by neurons [76] even if the natural function of extracellular Tau remains to be uncovered [77].

Tau protein sequence contains more than 85 phosphorylated or phosphorylable sites [78]. Hyperphosphorylation of Tau leads to conformational changes that notably impair its ability to bind to microtubules. Free monomers of misfolded Tau then start to accumulate, oligomerize and aggregate. During the aggregation pro- 
cess, repeated domains of Tau adopt a beta sheet conformation [79] and form filaments [80]. Tau aggregates can deposit in NFTs that are the hallmark of a group of diseases called tauopathies $[81,82]$, divided into primary tauopathies (Pick disease, progressive supranuclear palsy, frontotemporal dementia...) and secondary or mixed tauopathies (AD ...) characterized by different clinical features and pathological hallmarks, reviewed elsewhere [83]. Tauopathies particularly differ from the cell types exhibiting NFTs and Tau isoform aggregation [78]. Notably, in AD, NFTs are observed early in life and increase during aging [84]. The spatiotemporal progression of NFTs from the entorhinal cortex and the hippocampus to the isocortical areas has been shown to be correlated with cognitive deficits [85], supporting a pivotal role for Tau pathology and spreading in $\mathrm{AD}$-related memory impairments [86]. Interestingly, hypothalamus that plays a key role in the central control of energy metabolism has been also shown to display alterations in $\mathrm{AD}[87,88]$. In a study investigating 28 patients with $\mathrm{AD}, 22$ patients showed plaques and NFTs in the hypothalamus [87]. In the AD stages described by Braak, plaques and tangles are found in the hypothalamus at stages III and IV [84]. Interestingly, these stages correspond to early-moderate $\mathrm{AD}$, whereas disturbances in metabolism, such as weight loss, which is regulated by hypothalamus, are often described to appear prior to cognitive impairments. This could suggest that factors other than Tau and $A \beta$ accumulation in the hypothalamus could contribute to metabolic deregulation. Indeed, studies of early cases of $\mathrm{AD}$ show neuronal loss in several nuclei of the hypothalamus in the supraoptic nucleus, and the paraventricular nucleus and even more in the suprachiasmatic nucleus (SCN), with minimal deposits of Tau or A $\beta[89,90]$. Atrophy of the hypothalamus was also evidenced in other tauopathies such as behavioral variant frontotemporal dementia (bvFTD) [91]. SCN degeneration in AD and FTD was correlated with circadian rhythm deregulation of body temperature [92]. Notably, deregulation of body temperature is well characterized to promote Tau pathology in vivo [93-96]. Hyperphosphorylated Tau as well as NFTs [97] and atrophy [98] in the hypothalamus have also been reported in mouse models of tauopathies.

Tau hyperphosphorylation is the result of deregulation in a balance between kinases and phosphatases. More than 30 kinases have been described as regulating Tau phosphorylation in vitro, while only a few have been confirmed in vivo. Among them, GSK3- $\beta$ is an important kinase which phosphorylates Tau on more than 30 sites and seems to play a pivotal role in AD and NFT develop-

Mutual Relationship between Tau and Central Insulin Signalling ment [99]. All serine/threonine phosphatases in the brain are prone to dephosphorylate Tau in vitro except PP2C [100-104], with PP2A contributing to $71 \%$ of the phosphatase activity on Tau [105]. Notably, several kinases and phosphatases of the Tau protein are involved in the regulation of insulin signalling such as GSK3- $\beta$, AMPK, ERK, JNK, PP1, and PP2A (Fig. 1).

\section{Brain Insulin Resistance in AD and Tauopathies: Cause or Consequence?}

\section{The Brain of AD Patients Is Insulin Resistant}

Insulin resistance is defined as the inability of insulin to optimally stimulate the transport of glucose into the cell (hyperinsulinaemia or impaired glucose tolerance) as a result of altered insulin signalling [106]. In the brain, more particularly, insulin-resistance leads to reduced cerebral glucose metabolism that eventually causes neuronal loss or dysfunction [107]. Considering the prominent role exerted by insulin towards plasticity and cognition, it is not surprising that the $\mathrm{AD}$ brain has been described to exhibit an insulin-resistance state, the so-called "type 3 diabetes" [108, 109]. Indeed, CSF insulin levels have been described to be lower in $\mathrm{AD}$ patients than in healthy subjects $[110,111]$, although these data have not always been confirmed by others $[112,113]$. Some explained reduced CSF insulin levels by a decreased transport of insulin across the $\mathrm{BBB}$ as suggested by Banks et al. [118, 119] who reported that chronic plasma hyperinsulinaemia, often reported in $\mathrm{AD}$ patients [110, 114-117], impairs the transport of insulin into the brain. However, whether all AD patients with reduced CSF insulin exhibit hyperinsulinaemia remains to be established, and other mechanisms could be instrumental. The IR signalling pathway and ability to respond to insulin have been described to be strongly impaired in the brains of AD patients [120, 121]. A notable increase in inhibitory IRS-1 phosphorylation at serine 616 and 636/639 has been particularly observed [121]. Tau pathology would likely contribute to the establishment of such brain insulin resistance. Indeed, a study by Yarchoan et al. [122] found increased phosphorylation of serine IRS1 in primary tauopathies, including Pick disease, corticobasal degeneration and progressive supranuclear palsy, even to a lesser degree than in $\mathrm{AD}$.

\section{Consequences of Brain Insulin Resistance for}

Cognition, Longevity, and Metabolism

Considering the above-mentioned role of insulin in the regulation of synaptic plasticity and memory, a cor- 
relation between increased serine phosphorylation of IRS- 1 and cognitive scores in AD patients (episodic and working memory) sounds logical [121]. Moreover, changes in insulin signalling in different models of rodents led to memory impairments $[55,123]$ and other age-related cognitive alterations [124]. Noteworthy, paradoxically, deletion of IRS- 2 in AD mouse model has previously been shown to reduce amyloid deposition and to rescue behavioral deficits [54]. These protective effects could relate to the IGF-1 pathway rather than the insulin pathway since similar results have been reported in $\mathrm{AD}$ mouse models with altered IGF- 1 signalling $[125,126]$, suggesting a paradoxical action of IGF-1 and insulin in the brain [127].

The signalling pathway related to insulin may also relate to change in longevity. Studies on genetic polymorphisms in humans showed enrichment of a haplotype in the IR gene in Japanese semisupercentenarians [128], and Akt variants were found associated with longevity in three Caucasian cohorts [129]. Similarly, polymorphisms of several genes related to insulin signalling were associated with reduced mortality and improved cognitive function in elderly women in the Leiden 85-plus study [130]. Interestingly, mice with a genetic alteration of insulin signalling display increased longevity. For instance, deletion of IRS-2 in the mouse brain increases the life span of mice maintained on a high-energy diet [131]. Similar observations have been reported in mice deleted for the IRS-1 gene [132]. IRS- 1 and IRS-2 mediate actions of both insulin and IGF-1. The latter being strongly linked to longevity [133], these effects could likely reflect an IGF-1-dependent effect. The controversial effect of brain insulin signalling alterations on longevity and $\mathrm{AD}$ led Lovestone and Killick to make an interesting hypothesis. They suggested that relatively defective insulin signalling is an evolutionary acquisition of humans that allows us to live longer [134]. However, the molecular mechanisms that have evolved to increase longevity specifically induce $A D$, suggesting that $A D$ is in fact not a disorder of ageing but of longevity itself.

While brain insulin signalling finely tunes energy homeostasis and peripheral glucose homeostasis, much less is known about the potential impact of brain insulin resistance towards metabolic disturbances in AD. Metabolic alterations have been reported in $\mathrm{AD}$ patients, regardless of whether patients are diabetic or not. Weight loss was already described by Aloïs Alzheimer [135, 136] and it is now recognized as a clinical feature of $\mathrm{AD}$ [137], affecting $20-45 \%$ of patients [138-142]. Weight loss in patients with dementia is associated with accelerated pro- gression of $\mathrm{AD}$, higher rate of institutionalization [143] and increased mortality [144-146]. Although dementiaassociated weight loss often begins before the onset of the clinical syndrome and accelerates by the time of diagnosis, it is unclear if it is a cause or a consequence of $\mathrm{AD}$ pathology [147]. Metabolic deregulations in animal models of tauopathies resemble those found in patients with Tau-related dementia. Indeed, decreased body weight has been described in a mouse model of Tau deposition such as THY-22 [148] or Tg4510 [149, 150], sometimes despite increased feeding behavior [151]. Additionally, genetic deletion of Tau resulted in increased body weight [152]. Impaired satiation and increased feeding behavior [153], as well as changes in body temperature [154] were also observed in a mouse model combining amyloid plaques and Tau pathology (3xTgAD). In Tg4510 mice, weight loss was specific to fat mass and co-occurred with deregulation of metabolic rate [151] as well as disturbances in circadian rhythm [98]. In both cases, Tau pathology was found in the hypothalamus.

One could wonder if these metabolic alterations, appearing for most before the detection of pathological deposits in the brain, could really be the result of early deregulation of central insulin signalling. However, only rare observations support that brain insulin resistance may play a role in the metabolism of AD patients. First, paradoxical overeating concomitant with weight loss has been observed in patients with $\mathrm{AD}$ [155] as well as in FTD [156-158]. Second, an increased risk to develop type 2 diabetes has been reported in $\mathrm{AD}$ patients (35\% diabetics $+46 \%$ with glucose intolerance) [159]. Furthermore, some sparse studies report that $\mathrm{AD}$ patients can exhibit hyperinsulinaemia or alterations in glucose metabolism $[110,114-117,160]$.

What Is the Trigger for Brain Insulin Resistance in AD?

$\mathrm{AD}$ brain insulin resistance has been originally ascribed to the detrimental impact of $A \beta$ oligomers. $A \beta$ peptide in the oligomeric form can promote insulin resistance by competitively binding and internalizing IRs [161] and by increasing the phosphorylation of IRS- 1 and JNK [162] in vitro. In vivo, these results were confirmed in crabgrass macaques and APP/PS1 transgenic mice, which received intracerebroventricular (ICV) injections of $A \beta$ oligomers [162]. Consistently, several rodent models of amyloid pathology develop metabolic alterations such as glucose intolerance [163-166]. Particularly interesting is the observation of impaired glucose homeostasis following ICV injections of $A \beta$ oligomers [162]. Recent data also pointed out that ApoE4 could be strongly re- 
lated to the development of brain insulin resistance (Fig. 1) [167], ApoE4 significantly impairing insulin-IR interaction and IR trafficking [167].

While the impact of $A \beta$ oligomers on insulin resistance has been well established, the role of Tau has been poorly evaluated so far. Our recent study [168] demonstrated that Tau deletion induces a disruption of hippocampal response to insulin and impairs the hypothalamic anorexigenic effect of insulin associated with energy metabolism alterations (enhanced food intake and body weight, increased adipose tissue mass, hyperinsulinaemia and glucose intolerance). These findings strongly supported a function of Tau protein as a regulator of brain insulin signalling. The potential mechanism by which Tau regulates hippocampal response to insulin seems ascribed to the regulation of both IRS-1 and PTEN. Indeed, we reported decreased activation of IRS- 1 and Akt after insulin exposure in Tau KO mice, suggesting brain insulin resistance. This is consistent with altered IRS-1 activity in $\mathrm{AD}$ brains that correlates with NFTs deposition $[121,169,170]$, whereas a direct interaction between Tau and IRS- 1 has never been reported. On the other hand, we found that Tau interacts with PTEN, known to inhibit insulin signalling, reducing its lipid phosphatase activity (Fig. 1) [168]. Our study thus identified a novel function of Tau protein as a modulator of brain insulin signalling and highlighted a potential mechanistic explanation whereby alteration of insulin signalling would occur in $A D$ via pathological Tau loss-of-function. Importantly, a recent study confirmed that Tau deletion promoted alteration of glucose homeostasis [171]. Interestingly, this work suggested that peripheral metabolic impairment of Tau knockout mice could also be related to the ability of pancreatic Tau to regulate insulin synthesis and secretion [171]. Tau would therefore be prone to control peripheral metabolism through both central and pancreatic regulations. In line with such a role in metabolism, we have reported, using GWAS cohorts [172, 173], an association between Tau H1 haplotype, known to impact the risk of tauopathies [174], and glucose homeostasis in a glucose tolerance test. While the number of studies remained limited regarding the regulatory role of Tau towards brain insulin signalling and peripheral metabolism, other studies support this view. Indeed, previous works have reported colocalization and correlation between the decrease in total IRS-1 and IRS-2 along with increased phosphorylated IRS-1 on Ser ${ }^{636 / 639}$ and Ser ${ }^{616}$ in the brains of AD patients together with NFT deposition $[121,122,169$, 170]. Further, increased serine phosphorylation of IRS-1 has been clearly associated with primary tauopathies

Mutual Relationship between Tau and

Central Insulin Signalling
[122]. Moreover, a recent study by Rodriguez-Rodriguez et al. [175] reported accumulated insulin as oligomers in hyperphosphorylated Tau-bearing neurons in $\mathrm{AD}$ and other tauopathies. They notably demonstrated that insulin oligomer accumulation in neurons is dependent on Tau hyperphosphorylation and results in a decrease in IRs and alteration of Akt phosphorylation [175]. If one considers Tau hyperphosphorylation/pathology as leading, at least partially, to a Tau loss-of-function, this would suggest that impaired Tau function would lead to a defect of insulin signalling but also a defect of the hormone itself. Although this hypothesis warrants future evaluations, our current knowledge supports that Tau pathology is instrumental for brain insulin resistance in $\mathrm{AD}$ and pure tauopathies.

Overall, these data open the possibility that cognitive and metabolic deficits seen in $\mathrm{AD}$ patients are the consequence of a Tau loss-of-function. For a long time, Tau aggregation into NFTs was thought to be the only culprit of neurodegeneration and cognitive deficits. But obviously, previous observations supported that this is not the case $[176,177]$. More recent data ascribed Tau oligomers as detrimental species towards plasticity. Interestingly, as Tau oligomers [178], Tau deletion also impairs hippocampal plasticity and spatial behavior [179-182]. This raises the possibility that both "toxic gain of Tau function" and "loss of normal Tau function" play a role in the development of cognitive deficits in tauopathies. Respective contribution of both phenomena will need to be further elucidated in the future.

\section{Consequences of Insulin Resistance State on Tau} Lesions

Although the interest in the impact of Tau protein on insulin signalling in the brain is very recent, it has for many years been known that, conversely, insulin is capable of modulating Tau protein, mainly its phosphorylation state [183]. There are increasing data showing that insulin regulates Tau phosphorylation and could exacerbate NFT development in AD [184-189] (Fig. 1). In vivo, mice deficient in IRs in neurons show inhibition of the PI3K/Akt signalling pathway and exhibit Tau hyperphosphorylation [190]. Similarly, the deletion of IRS-2 causes inhibition of the PI3K/Akt pathway and therefore induces Tau hyperphosphorylation [188]. Overall, the pathological effect of brain insulin resistance on Tau has mostly been attributable to the modulation of several downstream pathways [183], involving some Tau kinases (GSK-3 $\beta$, JNK, ERK, and AMPK) and Tau phosphatases (PP2A and PP1), known to play a pivotal role in the de- 
Fig. 2. Impaired homeostasis between brain insulin signalling and Tau: mutual relationship and consequences on cognition.

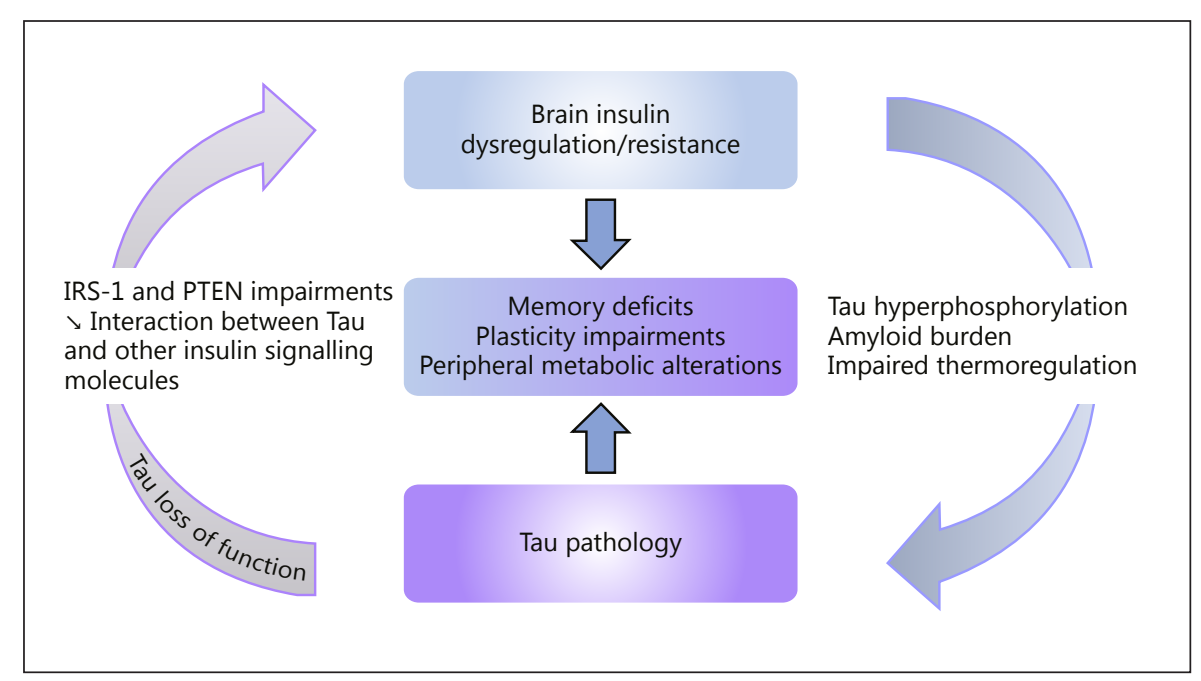

velopment of Tau pathology [99, 191-203]. Therefore, the chronic insulin signalling impairment seen in the brains of patients with $\mathrm{AD}$ and tauopathies is prone to favour the development of Tau pathology through the disruption of the balance between Tau kinases and phosphatases. Moreover, brain insulin signalling would also promote Tau pathology by favouring Tau cleavage [204, 205] and deregulating Tau alternative splicing [206].

\section{Inflammation: The Trigger of Both Tau Pathology and} Brain Insulin Resistance?

Neuroinflammation is an early and chronic event in AD. Glial activation resulting in the release of proinflammatory cytokines such as TNF- $\alpha$ and IL- $1 \beta$ seems to play a major role in the initiation and propagation of $\mathrm{AD}$ pathogenesis [207-209]. Besides $A \beta$, Tau pathology is itself prone to promote the development of innate and adaptive immune reaction in the brain $[210,211]$. Increased IL- $1 \beta$ has also been reported in the brains of progressive supranuclear palsy patients [212]. Moreover, neuroinflammation induced by lipopolysaccharide injection or traumatic brain injury exacerbated Tau pathology in transgenic mouse models of tauopathies [213-215]. Interestingly, numerous Tau kinases can be activated through inflammatory pathways such as JNK, ERK, Akt, or p38 [216]. These data suggest that neuroinflammation could contribute to, and maybe initiate, Tau pathology $[217,218]$. On the other hand, inflammatory processes are also well known to affect insulin signalling. Indeed, in periphery, inflammation linked to obesity induced insulin resistance in visceral adipose tissue through TNF- $\alpha$ [219]. Similar involvement of the TNF- $\alpha$ /JNK pathway has been suggested in $\mathrm{AD}$ brains to explain insulin resistance (Fig. 1). A study has particularly demonstrated that IRS- 1 inhibition caused by $\mathrm{A} \beta$ oligomers could be abolished with a TNF- $\alpha$-neutralizing antibody [220]. Interestingly, $\mathrm{Ma}$ et al. [169] have demonstrated that $\mathrm{A} \beta$ oligomers can induce both Tau hyperphosphorylation and insulin signalling alteration through the TNF- $\alpha / J N K$ pathway. Taken together, these data suggest that neuroinflammation seen in $\mathrm{AD}$ and other tauopathies could be the trigger of the vicious circle between Tau pathology and insulin resistance by promoting both.

\section{Conclusion}

Seminal works postulate that $\mathrm{AD}$ can be seen as "type 3 diabetes." The mechanisms underlying brain insulin resistance in $\mathrm{AD}$, formerly ascribed to amyloid pathology, appear however far more complex and involve Tau. A virtuous physiological homeostasis would exist in the brain between Tau and insulin-dependent pathways: Tau favouring insulin signalling and insulin signalling reducing Tau hyperphosphorylation/aggregation. A disruption of this homeostasis regulation induced by a Tau lossof-function, promoted by hyperphosphorylation/conformational changes, promoted by peripheral impairments (changes in the metabolic environment, stress...), neuroinflammation, or $\mathrm{A} \beta$, would then lead to insulin resistance and Tau hyperphosphorylation (Fig. 2). While it remains hard to define whether brain insulin resistance or Tau pathology is the primary event of this vicious circle, it is nevertheless well established that both are able to 
favour memory deficits, plasticity impairments, and peripheral metabolic alterations through different pathways. Any means to reinstate the homeostatic regulation between Tau and insulin signalling can then be considered of therapeutic interest. This could be directly achieved by activating IRs or targeting downstream pathways using PTP1B inhibitors [221], GLP-1 receptor agonists [162, 222, 223], or intranasal insulin administration $[224,225]$. Alternatively, one could imagine that strategies aimed at clearing pathological forms of Tau (such as Tau immunotherapy) [226, 227] could allow reestablishment of proper brain insulin signalling. Combined strategies aimed at reducing insulin resistance will thus be of high interest in the future.

\section{Acknowledgments}

Our laboratories are supported by grants from France Alzheimer/Fondation de France (InsTauBrain project), FHU VasCog research network (Lille, France), CoEN LiCEND and Programmes d'investissements d'avenir LabEx (excellence laboratory) DISTALZ (Development of Innovative Strategies for a Transdisciplinary approach to ALZheimer's disease). Our laboratories are also supported by ANR (ADORATAU to D.B., SPREADTAU and GRAND to L.B.), Fondation pour la Recherche Médicale, LECMA/Alzheimer Forschung Initiative, Fondation Plan Alzheimer, as well as Inserm, CNRS, Université Lille 2, Métropole Européenne de Lille, Région Nord/Pas-de-Calais, FEDER, DN2M. We also want to thank Alzheimer's Association, the NIH and Byrd Alzheimer's Institute for their support. This work was also supported by Biomedical Doctoral Awards from the Alzheimer Society of Canada (to M.G.).

\section{References}

$\checkmark 1$ Banting FG, Best CH, Collip JB, Campbell WR, Fletcher AA: Pancreatic extracts in the treatment of diabetes mellitus. Can Med Assoc J 1922;12:141-146.

-2 Havrankova J, Schmechel D, Roth J, Brownstein M: Identification of insulin in rat brain. Proc Natl Acad Sci USA 1978;75:5737-5741.

3 Havrankova J, Roth J, Brownstein MJ: Concentrations of insulin and insulin receptors in the brain are independent of peripheral insulin levels. Studies of obese and streptozotocintreated rodents. J Clin Invest 1979;64:636642.

4 Young WS 3rd: Periventricular hypothalamic cells in the rat brain contain insulin mRNA. Neuropeptides 1986;8:93-97.

-5 Devaskar SU, Giddings SJ, Rajakumar PA, Carnaghi LR, Menon RK, Zahm DS: Insulin gene expression and insulin synthesis in mammalian neuronal cells. J Biol Chem 1994; 269:8445-8454.

6 Duffy KR, Pardridge WM: Blood-brain barrier transcytosis of insulin in developing rabbits. Brain Research 1987;420:32-38.

7 Yang YJ, Hope ID, Ader M, Bergman RN: Insulin transport across capillaries is rate limiting for insulin action in dogs. J Clin Invest 1989;84:1620-1628.

8 Strubbe JH, Porte D Jr, Woods SC: Insulin responses and glucose levels in plasma and cerebrospinal fluid during fasting and refeeding in the rat. Physiol Behav 1988;44:205-208.

-9 Gray SM, Aylor KW, Barrett EJ: Unravelling the regulation of insulin transport across the brain endothelial cell. Diabetologia 2017;60: 1512-1521.

10 Posner BI, Kelly PA, Shiu RP, Friesen HG: Studies of insulin, growth hormone and prolactin binding: tissue distribution, species variation and characterization. Endocrinology 1974;95:521-531.

11 Dorn A, Bernstein HG, Rinne A, Ziegler M, Hahn HJ, Ansorge S: Insulin- and glucagon- like peptides in the brain. Anat Rec 1983;207: 69-77.

12 Kar S, Chabot JG, Quirion R: Quantitative autoradiographic localization of [125I]insulinlike growth factor I, [125I] insulin-like growth factor II, and [125I]insulin receptor binding sites in developing and adult rat brain. J Compar Neurol 1993;333:375-397.

13 Lowe WL Jr, Boyd FT, Clarke DW, Raizada MK, Hart C, LeRoith D: Development of brain insulin receptors: structural and functional studies of insulin receptors from whole brain and primary cell cultures. Endocrinology 1986;119:25-35

14 Heidenreich KA, Zahniser NR, Berhanu P, Brandenburg D, Olefsky JM: Structural differences between insulin receptors in the brain and peripheral target tissues. J Biol Chem 1983;258:8527-8530.

15 Marks JL, Porte D Jr, Stahl WL, Baskin DG: Localization of insulin receptor mRNA in rat brain by in situ hybridization. Endocrinology 1990;127:3234-3236.

16 Werther GA, Hogg A, Oldfield BJ, McKinley MJ, Figdor R, Allen AM, Mendelsohn FA: Localization and characterization of insulin receptors in rat brain and pituitary gland using in vitro autoradiography and computerized densitometry. Endocrinology 1987;121: 1562-1570.

17 White MF, Yenush L: The IRS-signaling system: a network of docking proteins that mediate insulin and cytokine action. Curr Topics Microbiol Immunol 1998;228:179-208.

-18 Konner AC, Janoschek R, Plum L, Jordan SD, Rother E, Ma X, Xu C, Enriori P, Hampel B, Barsh GS, Kahn CR, Cowley MA, Ashcroft FM, Bruning JC: Insulin action in AgRP-expressing neurons is required for suppression of hepatic glucose production. Cell Metab 2007;5:438-449.

19 Kasus-Jacobi A, Perdereau D, Tartare-Deckert S, Van Obberghen E, Girard J, Burnol AF:
Evidence for a direct interaction between insulin receptor substrate-1 and Shc. J Biol Chem 1997;272:17166-17170.

20 Holgado-Madruga M, Emlet DR, Moscatello DK, Godwin AK, Wong AJ: A Grb2-associated docking protein in EGF- and insulin-receptor signalling. Nature 1996;379:560-564.

21 Combettes-Souverain M, Issad T: Molecular basis of insulin action. Diabetes Metab 1998; 24:477-489.

22 Taguchi A, White MF: Insulin-like signaling, nutrient homeostasis, and life span. Annu Rev Physiol 2008;70:191-212.

23 Ghasemi R, Haeri A, Dargahi L, Mohamed Z, Ahmadiani A: Insulin in the brain: sources, localization and functions. Mol Neurobiol 2013;47:145-171.

24 Bruning JC, Gautam D, Burks DJ, Gillette J, Schubert M, Orban PC, Klein R, Krone W, Muller-Wieland D, Kahn CR: Role of brain insulin receptor in control of body weight and reproduction. Science 2000;289:2122-2125.

$\checkmark 25$ Elmquist JK, Elias CF, Saper CB: From lesions to leptin: hypothalamic control of food intake and body weight. Neuron 1999;22:221-232.

26 Cone RD: Anatomy and regulation of the central melanocortin system. Nat Neurosci 2005; 8:571-578

27 Horvath TL, Naftolin F, Kalra SP, Leranth C: Neuropeptide-Y innervation of beta-endorphin-containing cells in the rat mediobasal hypothalamus: a light and electron microscopic double immunostaining analysis. Endocrinology 1992;131:2461-2467.

28 Cowley MA, Smart JL, Rubinstein M, Cerdan MG, Diano S, Horvath TL, Cone RD, Low MJ: Leptin activates anorexigenic POMC neurons through a neural network in the arcuate nucleus. Nature 2001;411:480-484.

29 Pinto S, Roseberry AG, Liu H, Diano S, Shanabrough M, Cai X, Friedman JM, Horvath TL: Rapid rewiring of arcuate nucleus feeding circuits by leptin. Science 2004;304:110-115.
Mutual Relationship between Tau and Central Insulin Signalling
Neuroendocrinology 2018;107:181-195 DOI: $10.1159 / 000487641$ 
-30 Saper CB, Chou TC, Elmquist JK: The need to feed: homeostatic and hedonic control of eating. Neuron 2002;36:199-211.

- 31 Xu AW, Kaelin CB, Morton GJ, Ogimoto K, Stanhope K, Graham J, Baskin DG, Havel P, Schwartz MW, Barsh GS: Effects of hypothalamic neurodegeneration on energy balance. PLoS Biol 2005;3:e415.

- 32 Bewick GA, Gardiner JV, Dhillo WS, Kent AS, White NE, Webster Z, Ghatei MA, Bloom SR: Post-embryonic ablation of AgRP neurons in mice leads to a lean, hypophagic phenotype. FASEB J 2005; 19:1680-1682.

33 Gropp E, Shanabrough M, Borok E, Xu AW, Janoschek R, Buch T, Plum L, Balthasar N, Hampel B, Waisman A, Barsh GS, Horvath TL, Bruning JC: Agouti-related peptide-expressing neurons are mandatory for feeding. Nat Neurosci 2005;8:1289-1291.

- 34 Luquet S, Perez FA, Hnasko TS, Palmiter RD: NPY/AgRP neurons are essential for feeding in adult mice but can be ablated in neonates. Science 2005;310:683-685.

35 Cone RD, Cowley MA, Butler AA, Fan W, Marks DL, Low MJ: The arcuate nucleus as a conduit for diverse signals relevant to energy homeostasis. Int J Obesity 2001;25:S63-S67.

- 36 Benoit SC, Air EL, Coolen LM, Strauss R, Jackman A, Clegg DJ, Seeley RJ, Woods SC: The catabolic action of insulin in the brain is mediated by melanocortins. J Neurosci 2002; 22:9048-9052.

37 Loh K, Zhang L, Brandon A, Wang Q, Begg D, Qi Y, Fu M, Kulkarni R, Teo J, Baldock P, Bruning JC, Cooney G, Neely G, Herzog H: Insulin controls food intake and energy balance via NPY neurons. Mol Metab 2017;6: 574-584.

- 38 Sipols AJ, Baskin DG, Schwartz MW: Effect of intracerebroventricular insulin infusion on diabetic hyperphagia and hypothalamic neuropeptide gene expression. Diabetes 1995;44: 147-151.

- 39 Benoit SC, Air EL, Coolen LM, Strauss R, Jackman A, Clegg DJ, Seeley RJ, Woods SC: The catabolic action of insulin in the brain is mediated by melanocortins. J Neurosci 2002; 22:9048-9052.

-40 Konner AC, Hess S, Tovar S, Mesaros A, Sanchez-Lasheras C, Evers N, Verhagen LA, Bronneke HS, Kleinridders A, Hampel B, Kloppenburg P, Bruning JC: Role for insulin signaling in catecholaminergic neurons in control of energy homeostasis. Cell Metab 2011;13:720-728.

-41 Renner DB, Svitak AL, Gallus NJ, Ericson ME, Frey WH 2nd, Hanson LR: Intranasal delivery of insulin via the olfactory nerve pathway. J Pharm Pharmacol 2012;64:1709-1714.

-42 Flint A, Gregersen NT, Gluud LL, Moller BK, Raben A, Tetens I, Verdich C, Astrup A: Associations between postprandial insulin and blood glucose responses, appetite sensations and energy intake in normal weight and overweight individuals: a meta-analysis of test meal studies. Br J Nutr 2007;98:1725.
43 Hallschmid M, Higgs S, Thienel M, Ott V, Lehnert H: Postprandial administration of intranasal insulin intensifies satiety and reduces intake of palatable snacks in women. Diabetes 2012;61:782-789.

44 Jauch-Chara K, Friedrich A, Rezmer M, Melchert UH, H GS-E, Hallschmid M, Oltmanns KM: Intranasal insulin suppresses food intake via enhancement of brain energy levels in humans. Diabetes 2012;61:22612268.

45 Banks WA, Jaspan JB, Huang W, Kastin AJ: Transport of insulin across the blood-brain barrier: saturability at euglycemic doses of insulin. Peptides 1997;18:1423-1429.

46 Scherer T, O’Hare J, Diggs-Andrews K, Schweiger M, Cheng B, Lindtner C, Zielinski E, Vempati P, Su K, Dighe S, Milsom T, Puchowicz M, Scheja L, Zechner R, Fisher SJ, Previs SF, Buettner C: Brain insulin controls adipose tissue lipolysis and lipogenesis. Cell Metab 2011;13:183-194.

47 Obici S, Zhang BB, Karkanias G, Rossetti L: Hypothalamic insulin signaling is required for inhibition of glucose production. Nat Med 2002;8:1376-1382.

48 Hoyer S, Prem L, Sorbi S, Amaducci L: Stimulation of glycolytic key enzymes in cerebral cortex by insulin. Neuroreport 1993;4:991993.

49 Blázquez E, Velázquez E, Hurtado-Carneiro V, Ruiz-Albusac JM: Insulin in the brain: its pathophysiological implications for states related with central insulin resistance, type 2 diabetes and Alzheimer's disease. Front Endocrinol 2014;5:161.

50 El Messari S, Leloup C, Quignon M, Brisorgueil MJ, Penicaud L, Arluison M: Immunocytochemical localization of the insulin-responsive glucose transporter 4 (Glut4) in the rat central nervous system. J Compar Neurol 1998;399:492-512.

-51 Reagan LP, Rosell DR, Alves SE, Hoskin EK, McCall AL, Charron MJ, McEwen BS: GLUT8 glucose transporter is localized to excitatory and inhibitory neurons in the rat hippocampus. Brain Res 2002;932:129-134.

52 Piroli GG, Grillo CA, Hoskin EK, Znamensky V, Katz EB, Milner TA, McEwen BS, Charron MJ, Reagan LP: Peripheral glucose administration stimulates the translocation of GLUT8 glucose transporter to the endoplasmic reticulum in the rat hippocampus. J Compar Neurol 2002;452:103-114.

53 Moult PR, Harvey J: Hormonal regulation of hippocampal dendritic morphology and synaptic plasticity. Cell Adh Migr 2008;2:269275.

54 van der Heide LP, Kamal A, Artola A, Gispen WH, Ramakers GM: Insulin modulates hippocampal activity-dependent synaptic plasticity in a N-methyl-D-aspartate receptor and phosphatidyl-inositol-3-kinase-dependent manner. J Neurochem 2005;94:1158-1166.

55 Grillo CA, Piroli GG, Lawrence RC, Wrighten SA, Green AJ, Wilson SP, Sakai RR, Kelly SJ, Wilson MA, Mott DD, Reagan LP: Hippo- campal insulin resistance impairs spatial learning and synaptic plasticity. Diabetes 2015;64:3927-3936.

56 Skeberdis VA, Lan J, Zheng X, Zukin RS, Bennett MV: Insulin promotes rapid delivery of $\mathrm{N}$-methyl-D-aspartate receptors to the cell surface by exocytosis. Proc Natl Acad Sci USA 2001;98:3561-3566.

57 Wu SP, Lu KT, Chang WC, Gean PW: Involvement of mitogen-activated protein kinase in hippocampal long-term potentiation. J Biomed Sci 1999;6:409-417.

58 Sanna PP, Cammalleri M, Berton F, Simpson C, Lutjens R, Bloom FE, Francesconi W: Phosphatidylinositol 3-kinase is required for the expression but not for the induction or the maintenance of long-term potentiation in the hippocampal CA1 region. J Neurosci 2002;22: 3359-3365.

59 Abbott MA, Wells DG, Fallon JR: The insulin receptor tyrosine kinase substrate $\mathrm{p} 58 / 53$ and the insulin receptor are components of CNS synapses. J Neurosci 1999;19:7300-7308.

60 Spinelli M, Fusco S, Mainardi M, Scala F, Natale F, Lapenta R, Mattera A, Rinaudo M, Li Puma DD, Ripoli C, Grassi A, D’Ascenzo M, Grassi C: Brain insulin resistance impairs hippocampal synaptic plasticity and memory by increasing GluA1 palmitoylation through FoxO3a. Nat Commun 2017;8:2009.

-61 Benedict C, Kern W, Schultes B, Born J, Hallschmid M: Differential sensitivity of men and women to anorexigenic and memory-improving effects of intranasal insulin. J Clin Endocrinol Metab 2008;93:1339-1344.

-62 Benedict C, Hallschmid M, Hatke A, Schultes B, Fehm HL, Born J, Kern W: Intranasal insulin improves memory in humans. Psychoneuroendocrinology 2004;29:1326-1334.

63 Kern W, Peters A, Fruehwald-Schultes B, Deininger E, Born J, Fehm HL: Improving influence of insulin on cognitive functions in humans. Neuroendocrinology 2001;74:270280.

64 S. Roriz-Filho J, Sá-Roriz TM, Rosset I, Camozzato AL, Santos AC, Chaves MLF, Moriguti JC, Roriz-Cruz M: (Pre)diabetes, brain aging, and cognition. Biochim Biophys Acta 2009;1792:432-443.

65 Kang JM, Lee SY, Seo S, Jeong HJ, Woo SH, Lee H, Lee YB, Yeon BK, Shin DH, Park KH, Kang H, Okamura N, Furumoto S, Yanai K, Villemagne VL, Seong JK, Na DL, Ido T, Cho J, Lee KM, Noh Y: Tau positron emission tomography using [18F]THK5351 and cerebral glucose hypometabolism in Alzheimer's disease. Neurobiol Aging 2017;59:210-219.

66 Weingarten MD, Lockwood AH, Hwo SY, Kirschner MW: A protein factor essential for microtubule assembly. Proc Natl Acad Sci USA 1975;72:1858-1862.

67 Grundke-Iqbal I, Iqbal K, Tung YC, Quinlan M, Wisniewski HM, Binder LI: Abnormal phosphorylation of the microtubule-associated protein tau (tau) in Alzheimer cytoskeletal pathology. Proc Natl Acad Sci USA 1986;83: 4913-4917. 
68 Brion JP: Immunological demonstration of tau protein in neurofibrillary tangles of Alzheimer's disease. J Alzheimers Dis 2006;9: 177-185.

-69 Pollock NJ, Mirra SS, Binder LI, Hansen LA, Wood JG: Filamentous aggregates in Pick's disease, progressive supranuclear palsy, and Alzheimer's disease share antigenic determinants with microtubule-associated protein, tau. Lancet 1986;2:1211.

70 Goedert M, Spillantini MG, Jakes R, Rutherford D, Crowther RA: Multiple isoforms of human microtubule-associated protein tau: sequences and localization in neurofibrillary tangles of Alzheimer's disease. Neuron 1989; 3:519-526.

-71 Caillet-Boudin ML, Buee L, Sergeant N, Lefebvre B: Regulation of human MAPT gene expression. Mol Neurodegener 2015;10:28.

-72 Cassimeris L, Spittle C: Regulation of microtubule-associated proteins. Int Rev Cytol 2001;210:163-226.

73 Arendt T, Stieler JT, Holzer M: Tau and tauopathies. Brain Res Bull 2016;126:238292.

-74 Ittner LM, Ke YD, Delerue F, Bi M, Gladbach A, van Eersel J, Wolfing H, Chieng BC, Christie MJ, Napier IA, Eckert A, Staufenbiel M, Hardeman E, Gotz J: Dendritic function of tau mediates amyloid-beta toxicity in Alzheimer's disease mouse models. Cell 2010; 142:387-397.

-75 Sultan A, Nesslany F, Violet M, Begard S, Loyens A, Talahari S, Mansuroglu Z, Marzin D, Sergeant N, Humez S, Colin M, Bonnefoy E, Buee L, Galas MC: Nuclear tau, a key player in neuronal DNA protection. J Biol Chem 2011;286:4566-4575.

76 Pooler AM, Phillips EC, Lau DH, Noble W, Hanger DP: Physiological release of endogenous tau is stimulated by neuronal activity. EMBO Rep 2013;14:389-394.

-77 Sotiropoulos I, Galas MC, Silva JM, Skoulakis E, Wegmann S, Maina MB, Blum D, Sayas CL, Mandelkow EM, Mandelkow E, Spillantini MG, Sousa N, Avila J, Medina M, Mudher A, Buee L: Atypical, non-standard functions of the microtubule associated Tau protein. Acta Neuropathol Commun 2017;5:91.

-78 Sergeant N, Bretteville A, Hamdane M, Caillet-Boudin ML, Grognet P, Bombois S, Blum D, Delacourte A, Pasquier F, Vanmechelen E, Schraen-Maschke S, Buee L: Biochemistry of Tau in Alzheimer's disease and related neurological disorders. Expert Rev Proteomics 2008;5:207-224.

-79 Berriman J, Serpell LC, Oberg KA, Fink AL, Goedert M, Crowther RA: Tau filaments from human brain and from in vitro assembly of recombinant protein show cross-beta structure. Proc Natl Acad Sci USA 2003;100:90349038.

\$0 King ME, Ahuja V, Binder LI, Kuret J: Ligand-dependent tau filament formation: implications for Alzheimer's disease progression. Biochemistry 1999;38:14851-14859.
81 Spillantini MG, Bird TD, Ghetti B: Frontotemporal dementia and Parkinsonism linked to chromosome 17: a new group of tauopathies. Brain Pathol 1998;8:387-402.

82 Lee VM, Goedert M, Trojanowski JQ: Neurodegenerative tauopathies. Annu Rev Neurosci 2001;24:1121-1159.

83 Lebouvier T, Pasquier F, Buee L: Update on tauopathies. Curr Opin Neurol 2017;30:589598.

84 Braak H, Braak E: Neuropathological stageing of Alzheimer-related changes. Acta Neuropathol 1991;82:239-259.

85 Duyckaerts C, Hauw JJ: Diagnosis and staging of Alzheimer disease. Neurobiol Aging 1997; 18:S33-S42.

86 Dujardin S, Colin M, Buee L: Invited review: animal models of tauopathies and their implications for research/translation into the clinic. Neuropathol Appl Neurobiol 2015;41:5980.

87 McDuff T, Sumi SM: Subcortical degeneration in Alzheimer's disease. Neurology 1985; 35:123-126.

88 Vercruysse P, Vieau D, Blum D, Petersén Å, Dupuis L: Hypothalamic alterations in neurodegenerative diseases and their relation to abnormal energy metabolism. Front $\mathrm{Mol} \mathrm{Neu-}$ rosci 2018;11:2.

89 Swaab DF, Fliers E, Partiman TS: The suprachiasmatic nucleus of the human brain in relation to sex, age and senile dementia. Brain Res 1985;342:37-44.

90 Baloyannis SJ, Mavroudis I, Mitilineos D, Baloyannis IS, Costa VG: The hypothalamus in Alzheimer's disease: a Golgi and electron microscope study. Am J Alzheimers Dis Other Demen 2015;30:478-487.

91 Piguet O, Petersen A, Yin Ka Lam B, Gabery S, Murphy K, Hodges JR, Halliday GM: Eating and hypothalamus changes in behavioralvariant frontotemporal dementia. Ann Neurol 2011;69:312-319.

92 Harper DG, Stopa EG, Kuo-Leblanc V, McKee AC, Asayama K, Volicer L, Kowall N, Satlin A: Dorsomedial SCN neuronal subpopulations subserve different functions in human dementia. Brain 2008;131:1609-1617.

93 El Khoury NB, Gratuze M, Petry F, Papon MA, Julien C, Marcouiller F, Morin F, Nicholls SB, Calon F, Hebert SS, Marette A, Planel E: Hypothermia mediates age-dependent increase of tau phosphorylation in $\mathrm{db} / \mathrm{db}$ mice. Neurobiol Dis 2016;88:55-65.

94 Gratuze M, El Khoury NB, Turgeon A, Julien C, Marcouiller F, Morin F, Whittington RA, Marette A, Calon F, Planel E: Tau hyperphosphorylation in the brain of ob/ob mice is due to hypothermia: importance of thermoregulation in linking diabetes and Alzheimer's disease. Neurobiol Dis 2017;98:1-8.

95 Tournissac M, Vandal M, Francois A, Planel E, Calon F: Old age potentiates cold-induced tau phosphorylation: linking thermoregulatory deficit with Alzheimer's disease. Neurobiol Aging 2017;50:25-29.
96 Vandal M, White PJ, Tournissac M, Tremblay C, St-Amour I, Drouin-Ouellet J, Bousquet M, Traversy MT, Planel E, Marette A, Calon F: Impaired thermoregulation and beneficial effects of thermoneutrality in the 3xTg-AD model of Alzheimer's disease. Neurobiol Aging 2016;43:47-57.

$\$ 97$ Li T, Braunstein KE, Zhang J, Lau A, Sibener L, Deeble C, Wong PC: The neuritic plaque facilitates pathological conversion of tau in an Alzheimer's disease mouse model. Nat Commun 2016;7:12082.

-98 Stevanovic K, Yunus A, Joly-Amado A, Gordon M, Morgan D, Gulick D, Gamsby J: Disruption of normal circadian clock function in a mouse model of tauopathy. Exp Neurol 2017;294:58-67.

-99 Avila J, Leon-Espinosa G, Garcia E, GarciaEscudero V, Hernandez F, Defelipe J: Tau phosphorylation by GSK3 in different conditions. Int J Alzheimers Dis 2012;2012: 578373.

100 Liu F, Grundke-Iqbal I, Iqbal K, Gong CX: Contributions of protein phosphatases PP1, PP2A, PP2B and PP5 to the regulation of tau phosphorylation. Eur J Neurosci 2005;22: 1942-1950.

101 Gong CX, Lidsky T, Wegiel J, Zuck L, Grundke-Iqbal I, Iqbal K: Phosphorylation of microtubule-associated protein tau is regulated by protein phosphatase $2 \mathrm{~A}$ in mammalian brain. Implications for neurofibrillary degeneration in Alzheimer's disease. J Biol Chem 2000;275:5535-5544.

102 Rahman A, Grundke-Iqbal I, Iqbal K: PP2B isolated from human brain preferentially dephosphorylates Ser-262 and Ser-396 of the Alzheimer disease abnormally hyperphosphorylated tau. J Neural Transm (Vienna) 2006;113:219-230.

103 Gong CX, Liu F, Wu G, Rossie S, Wegiel J, Li L, Grundke-Iqbal I, Iqbal K: Dephosphorylation of microtubule-associated protein tau by protein phosphatase 5 . J Neurochem 2004;88:298-310.

104 Yamamoto H, Saitoh Y, Fukunaga K, Nishimura H, Miyamoto E: Dephosphorylation of microtubule proteins by brain protein phosphatases 1 and $2 \mathrm{~A}$, and its effect on microtubule assembly. J Neurochem 1988; 50:1614-1623.

105 Torrent L, Ferrer I: PP2A and Alzheimer disease. Curr Alzheimer Res 2012;9:248256.

106 Reaven GM: Banting lecture 1988. Role of insulin resistance in human disease. Diabetes 1988;37:1595-1607.

107 Berger AL: Insulin resistance and reduced brain glucose metabolism in the aetiology of Alzheimer's disease. J Insulin Resist 2016; 1:a15.

108 Hoyer S: Is sporadic Alzheimer disease the brain type of non-insulin dependent diabetes mellitus? A challenging hypothesis. J Neural Transm (Vienna) 1998;105:415-422.
Mutual Relationship between Tau and Central Insulin Signalling
Neuroendocrinology 2018;107:181-195 DOI: $10.1159 / 000487641$ 
-109 Steen E, Terry BM, Rivera EJ, Cannon JL, Neely TR, Tavares R, Xu XJ, Wands JR, de la Monte SM: Impaired insulin and insulinlike growth factor expression and signaling mechanisms in Alzheimer's disease - is this type 3 diabetes? J Alzheimers Dis 2005;7:6380.

110 Craft S, Peskind E, Schwartz MW, Schellenberg GD, Raskind M, Porte D Jr: Cerebrospinal fluid and plasma insulin levels in Alzheimer's disease: relationship to severity of dementia and apolipoprotein E genotype. Neurology 1998;50:164-168.

111 Gil-Bea FJ, Solas M, Solomon A, Mugueta C, Winblad B, Kivipelto M, Ramirez MJ, Cedazo-Minguez A: Insulin levels are decreased in the cerebrospinal fluid of women with prodomal Alzheimer's disease. J Alzheimers Dis 2010;22:405-413.

-112 Molina JA, Jimenez-Jimenez FJ, Vargas C, Gomez P, de Bustos F, Gomez-Escalonilla C, Zurdo M, Tallon A, Martinez-Salio A, PortaEtessam J, Villanueva C, Arenas J: Cerebrospinal fluid levels of insulin in patients with Alzheimer's disease. Acta Neurol Scand 2002;106:347-350.

-113 Fujisawa Y, Sasaki K, Akiyama K: Increased insulin levels after OGTT load in peripheral blood and cerebrospinal fluid of patients with dementia of Alzheimer type. Biol Psychiatry 1991;30:1219-1228.

-114 Bucht G, Adolfsson R, Lithner F, Winblad B: Changes in blood glucose and insulin secretion in patients with senile dementia of $\mathrm{Alz}$ heimer type. Acta Med Scand 1983;213:387392.

115 Fujisawa Y, Sasaki K, Akiyama K: Increased insulin levels after OGTT load in peripheral blood and cerebrospinal fluid of patients with dementia of Alzheimer type. Biol Psychiatry 1991;30:1219-1228.

116 Ma J, Zhang W, Wang HF, Wang ZX, Jiang T, Tan MS, Yu JT, Tan L: Peripheral blood adipokines and insulin levels in patients with Alzheimer's disease: a replication study and meta-analysis. Curr Alzheimer Res 2016;13:223-233.

-117 Stolk RP, Breteler MM, Ott A, Pols HA, Lamberts SW, Grobbee DE, Hofman A: Insulin and cognitive function in an elderly population. The Rotterdam Study. Diabetes Care 1997;20:792-795.

-118 Banks WA, Jaspan JB, Kastin AJ: Effect of diabetes mellitus on the permeability of the blood-brain barrier to insulin. Peptides 1997; 18:1577-1584.

119 Banks WA, Jaspan JB, Kastin AJ: Selective, physiological transport of insulin across the blood-brain barrier: novel demonstration by species-specific radioimmunoassays. Peptides 1997;18:1257-1262.

$>120$ Moloney AM, Griffin RJ, Timmons S, O’Connor R, Ravid R, O’Neill C: Defects in IGF-1 receptor, insulin receptor and IRS-1/2 in Alzheimer's disease indicate possible resistance to IGF-1 and insulin signalling. Neurobiol Aging 2010;31:224-243.
121 Talbot K, Wang HY, Kazi H, Han LY, Bakshi KP, Stucky A, Fuino RL, Kawaguchi KR, Samoyedny AJ, Wilson RS, Arvanitakis Z, Schneider JA, Wolf BA, Bennett DA, Trojanowski JQ, Arnold SE: Demonstrated brain insulin resistance in Alzheimer's disease patients is associated with IGF-1 resistance, IRS-1 dysregulation, and cognitive decline. J Clin Invest 2012;122:13161338.

122 Yarchoan M, Toledo JB, Lee EB, Arvanitakis Z, Kazi H, Han LY, Louneva N, Lee VM, Kim SF, Trojanowski JQ, Arnold SE: Abnormal serine phosphorylation of insulin receptor substrate 1 is associated with tau pathology in Alzheimer's disease and tauopathies. Acta Neuropathol 2014;128:679-689.

123 McNay EC, Ong CT, McCrimmon RJ, Cresswell J, Bogan JS, Sherwin RS: Hippocampal memory processes are modulated by insulin and high-fat-induced insulin resistance. Neurobiol Learn Mem 2010;93:546553.

124 Kleinridders A, Cai W, Cappellucci L, Ghazarian A, Collins WR, Vienberg SG, Pothos EN, Kahn CR: Insulin resistance in brain alters dopamine turnover and causes behavioral disorders. Proc Natl Acad Sci USA 2015;112:3463-3468.

125 Freude S, Hettich MM, Schumann C, Stohr O, Koch L, Kohler C, Udelhoven M, Leeser U, Muller M, Kubota N, Kadowaki T, Krone W, Schroder H, Bruning JC, Schubert M: Neuronal IGF-1 resistance reduces Abeta accumulation and protects against premature death in a model of Alzheimer's disease. FASEB J 2009;23:3315-3324.

126 Cohen E, Paulsson JF, Blinder P, BurstynCohen T, Du D, Estepa G, Adame A, Pham HM, Holzenberger M, Kelly JW, Masliah E, Dillin A: Reduced IGF-1 signaling delays age-associated proteotoxicity in mice. Cell 2009; 139:1157-1169.

127 Steculorum SM, Solas M, Bruning JC: The paradox of neuronal insulin action and resistance in the development of aging-associated diseases. Alzheimers Dement 2014; 10:S3-S11.

-128 Kojima T, Kamei H, Aizu T, Arai Y, Takayama M, Nakazawa S, Ebihara Y, Inagaki $H$, Masui Y, Gondo Y, Sakaki Y, Hirose N: Association analysis between longevity in the Japanese population and polymorphic variants of genes involved in insulin and insulinlike growth factor 1 signaling pathways. Exp Gerontol 2004;39:1595-1598.

129 Pawlikowska L, Hu D, Huntsman S, Sung A, Chu C, Chen J, Joyner AH, Schork NJ, Hsueh WC, Reiner AP, Psaty BM, Atzmon G, Barzilai N, Cummings SR, Browner WS, Kwok PY, Ziv E, Study of Osteoporotic Fractures: Association of common genetic variation in the insulin/IGF1 signaling pathway with human longevity. Aging Cell 2009;8: 460-472.

130 Ling CH, Taekema D, de Craen AJ, Gussekloo J, Westendorp RG, Maier AB: Handgrip strength and mortality in the oldest old population: the Leiden 85-plus study. CMAJ 2010;182:429-435.

131 Taguchi A, Wartschow LM, White MF: Brain IRS2 signaling coordinates life span and nutrient homeostasis. Science 2007;317: 369-372.

132 Selman C, Lingard S, Choudhury AI, Batterham RL, Claret M, Clements M, Ramadani F, Okkenhaug K, Schuster E, Blanc E, Piper MD, Al-Qassab H, Speakman JR, Carmignac D, Robinson IC, Thornton JM, Gems D, Partridge L, Withers DJ: Evidence for lifespan extension and delayed age-related biomarkers in insulin receptor substrate 1 null mice. FASEB J 2008;22:807-818.

133 Junnila RK, List EO, Berryman DE, Murrey JW, Kopchick JJ: The GH/IGF-1 axis in ageing and longevity. Nat Rev Endocrinol 2013; 9:366-376.

134 Craft S, Christen Y; Fondation IPSEN pour la recherche thérapeutique: Diabetes, Insulin, and Alzheimer's Disease. Heidelberg, Springer, 2010.

135 Gillette GS, Abellan VK, Alix E, Andrieu S, Belmin J, Berrut G, Bonnefoy M, Brocker P, Constans T, Ferry M, Ghisolfi-Marque A, Girard L, Gonthier R, Guerin O, Hervy MP, Jouanny P, Laurain MC, Lechowski L, Nourhashemi F, Raynaud-Simon A, Ritz P, Roche J, Rolland Y, Salva T, Vellas B; IANA (International Academy on Nutrition and Aging) Expert Group: Weight loss and Alzheimer's disease. J Nutr Health Aging 2007; 11:38-48.

136 Tamura BK, Masaki KH, Blanchette P: Weight loss in patients with Alzheimer's disease. J Nutr Elderly 2007;26:21-38.

137 McKhann G, Drachman D, Folstein M, Katzman R, Price D, Stadlan EM: Clinical diagnosis of Alzheimer's disease: report of the NINCDS-ADRDA Work Group under the auspices of Department of Health and Human Services Task Force on Alzheimer's Disease. Neurology 1984;34:939-944.

138 Gillette-Guyonnet S, Nourhashemi F, Andrieu S, de Glisezinski I, Ousset PJ, Riviere D, Albarede JL, Vellas B: Weight loss in Alzheimer disease. Am J Clin Nutr 2000;71: 637s-642s.

139 Guerin O, Soto ME, Brocker P, Robert PH, Benoit M, Vellas B: Nutritional status assessment during Alzheimer's disease: results after one year (the REAL French Study Group). J Nutr Health Aging 2005;9: 81-84.

140 Gillette-Guyonnet S, Cortes F, Cantet C, Vellas B: Long-term cholinergic treatment is not associated with greater risk of weight loss during Alzheimer's disease: data from the French REAL.FR cohort. J Nutr Health Aging 2005;9:69-73.

141 Guerin O, Andrieu S, Schneider SM, Milano M, Boulahssass R, Brocker P, Vellas B: Different modes of weight loss in Alzheimer disease: a prospective study of 395 patients. Am J Clin Nutr 2005;82:435-441. 
$>_{142}$ Vellas B, Lauque S, Gillette-Guyonnet S, Andrieu S, Cortes F, Nourhashemi F, Cantet C, Ousset PJ, Grandjean H: Impact of nutritional status on the evolution of Alzheimer's disease and on response to acetylcholinesterase inhibitor treatment. J Nutr Health Aging 2005;9:75-80.

-143 Andrieu S, Reynish W, Nourhashemi F, Ousset PJ, Grandjean H, Grand A, Albarede JL, Vellas B: Nutritional risk factors for institutional placement in Alzheimer's disease after one year follow-up. J Nutr Health Aging 2001;5:113-117.

144 Faxen-Irving G, Basun H, Cederholm T: Nutritional and cognitive relationships and long-term mortality in patients with various dementia disorders. Age Ageing 2005;34: 136-141.

145 Gambassi G, Landi F, Lapane KL, Sgadari A, Mor V, Bernabei R: Predictors of mortality in patients with Alzheimer's disease living in nursing homes. J Neurol Neurosurg Psychiatry 1999;67:59-65.

$\checkmark 146$ White H, Pieper C, Schmader K: The association of weight change in Alzheimer's disease with severity of disease and mortality: a longitudinal analysis. J Am Geriatr Soc 1998; 46:1223-1227.

-147 Inelmen EM, Sergi G, Coin A, Girardi A, Manzato E: An open-ended question: Alzheimer's disease and involuntary weight loss: which comes first? Aging Clin Exp Res 2010;22:192-197.

148 Leboucher A, Laurent C, Fernandez-Gomez FJ, Burnouf S, Troquier L, Eddarkaoui S, Demeyer D, Caillierez R, Zommer N, Vallez E, Bantubungi K, Breton C, Pigny P, BueeScherrer V, Staels B, Hamdane M, Tailleux A, Buee L, Blum D: Detrimental effects of diet-induced obesity on tau pathology are independent of insulin resistance in tau transgenic mice. Diabetes 2013;62:16811688.

149 Brownlow ML, Benner L, D’Agostino D, Gordon MN, Morgan D: Ketogenic diet improves motor performance but not cognition in two mouse models of Alzheimer's pathology. PLoS One 2013;8:e75713.

150 Brownlow ML, Joly-Amado A, Azam S, Elza M, Selenica ML, Pappas C, Small B, Engelman R, Gordon MN, Morgan D: Partial rescue of memory deficits induced by calorie restriction in a mouse model of tau deposition. Behav Brain Res 2014;271:79-88.

151 Joly-Amado A, Serraneau KS, Brownlow M, Marin de Evsikova C, Speakman JR, Gordon MN, Morgan D: Metabolic changes over the course of aging in a mouse model of tau deposition. Neurobiol Aging 2016;44:62-73.

152 Morris M, Hamto P, Adame A, Devidze N, Masliah E, Mucke L: Age-appropriate cognition and subtle dopamine-independent motor deficits in aged tau knockout mice. Neurobiol Aging 2013;34:1523-1529.

-153 Adebakin A, Bradley J, Gumusgoz S, Waters EJ, Lawrence CB: Impaired satiation and increased feeding behaviour in the triple- transgenic Alzheimer's disease mouse model. PLoS One 2012;7:e45179.

154 Knight EM, Brown TM, Gumusgoz S, Smith JC, Waters EJ, Allan SM, Lawrence CB: Agerelated changes in core body temperature and activity in triple-transgenic Alzheimer's disease (3xTgAD) mice. Dis Model Mech 2013;6:160-170.

155 Wolf-Klein GP, Silverstone FA, Levy AP: Nutritional patterns and weight change in Alzheimer patients. Int Psychogeriatr 1992; 4:103-118.

156 Piguet O: Eating disturbance in behaviouralvariant frontotemporal dementia. J Mol Neurosci 2011;45:589-593.

157 Bozeat S, Gregory CA, Ralph MA, Hodges JR: Which neuropsychiatric and behavioural features distinguish frontal and temporal variants of frontotemporal dementia from Alzheimer's disease? J Neurol Neurosurg Psychiatry 2000;69:178-186.

158 Snowden JS, Bathgate D, Varma A, Blackshaw A, Gibbons ZC, Neary D: Distinct behavioural profiles in frontotemporal dementia and semantic dementia. J Neurol Neurosurg Psychiatry 2001;70:323-332.

159 Janson J, Laedtke T, Parisi JE, O'Brien P, Petersen RC, Butler PC: Increased risk of type 2 diabetes in Alzheimer disease. Diabetes 2004;53:474-481.

160 Razay G, Wilcock GK: Hyperinsulinaemia and Alzheimer's disease. Age Ageing 1994; 23:396-399.

161 Zhao WQ, De Felice FG, Fernandez S, Chen H, Lambert MP, Quon MJ, Krafft GA, Klein WL: Amyloid beta oligomers induce impairment of neuronal insulin receptors. FASEB J 2008;22:246-260.

162 Bomfim TR, Forny-Germano L, Sathler LB, Brito-Moreira J, Houzel JC, Decker H, Silverman MA, Kazi H, Melo HM, McClean PL, Holscher C, Arnold SE, Talbot K, Klein WL, Munoz DP, Ferreira ST, De Felice FG: An anti-diabetes agent protects the mouse brain from defective insulin signaling caused by Alzheimer's disease-associated Abeta oligomers. J Clin Invest 2012;122:1339-1353.

163 Jimenez-Palomares M, Ramos-Rodriguez JJ, Lopez-Acosta JF, Pacheco-Herrero M, Lechuga-Sancho AM, Perdomo G, Garcia-Alloza M, Cozar-Castellano I: Increased Abeta production prompts the onset of glucose intolerance and insulin resistance. Am J Physiol Endocrinol Metab 2012;302:E1373-E1380.

164 Mody N, Agouni A, McIlroy GD, Platt B, Delibegovic M: Susceptibility to diet-induced obesity and glucose intolerance in the APP (SWE)/PSEN1 (A246E) mouse model of Alzheimer's disease is associated with increased brain levels of protein tyrosine phosphatase 1B (PTP1B) and retinol-binding protein 4 (RBP4), and basal phosphorylation of S6 ribosomal protein. Diabetologia 2011; 54:2143-2151.

165 Vandal M, White PJ, Chevrier G, Tremblay C, St-Amour I, Planel E, Marette A, Calon F: Agedependent impairment of glucose tolerance in the 3xTg-AD mouse model of Alzheimer's disease. FASEB J 2015;29:4273-4284.

166 Clarke JR, Lyra ESNM, Figueiredo CP, Frozza RL, Ledo JH, Beckman D, Katashima CK, Razolli D, Carvalho BM, Frazao R, Silveira MA, Ribeiro FC, Bomfim TR, Neves FS, Klein WL, Medeiros R, LaFerla FM, Carvalheira JB, Saad MJ, Munoz DP, Velloso LA, Ferreira ST, De Felice FG: Alzheimerassociated Abeta oligomers impact the central nervous system to induce peripheral metabolic deregulation. EMBO Mol Med 2015;7:190-210.

167 Zhao N, Liu CC, Van Ingelgom AJ, Martens YA, Linares C, Knight JA, Painter MM, Sullivan PM, Bu G: Apolipoprotein E4 impairs neuronal insulin signaling by trapping insulin receptor in the endosomes. Neuron 2017; 96:115-129 e115.

168 Marciniak E, Leboucher A, Caron E, Ahmed T, Tailleux A, Dumont J, Issad T, Gerhardt E, Pagesy P, Vileno M, Bournonville C, Hamdane M, Bantubungi K, Lancel S, Demeyer D, Eddarkaoui S, Vallez E, Vieau D, Humez S, Faivre E, Grenier-Boley B, Outeiro TF, Staels B, Amouyel P, Balschun D, Buee L, Blum D: Tau deletion promotes brain insulin resistance. J Exp Med 2017; 214:2257-2269.

169 Ma QL, Yang F, Rosario ER, Ubeda OJ, Beech W, Gant DJ, Chen PP, Hudspeth B, Chen C, Zhao Y, Vinters HV, Frautschy SA, Cole GM: Beta-amyloid oligomers induce phosphorylation of tau and inactivation of insulin receptor substrate via c-Jun N-terminal kinase signaling: suppression by omega-3 fatty acids and curcumin. J Neurosci 2009;29:9078-9089.

170 Moloney AM, Griffin RJ, Timmons S, O’Connor R, Ravid R, O’Neill C: Defects in IGF-1 receptor, insulin receptor and IRS-1/2 in Alzheimer's disease indicate possible resistance to IGF-1 and insulin signalling. Neurobiol Aging 2010;31:224-243.

171 Wijesekara N, Gonçalves RA, Ahrens R, De Felice FG, Fraser PE: Tau ablation in mice leads to pancreatic beta cell dysfunction and glucose intolerance. FASEB J DOI: 10.1096/ fj.201701352.

172 Prokopenko I, Poon W, Magi R, Prasad BR, et al: A central role for GRB10 in regulation of islet function in man. PLoS Genet 2014; 10:e1004235.

173 Saxena R, Hivert MF, Langenberg C, Tanaka $\mathrm{T}$, et al: Genetic variation in GIPR influences the glucose and insulin responses to an oral glucose challenge. Nat Genet 2010;42:142148.

174 Pittman AM, Myers AJ, Abou-Sleiman P, Fung HC, Kaleem M, Marlowe L, Duckworth J, Leung D, Williams D, Kilford L, Thomas N, Morris CM, Dickson D, Wood NW, Hardy J, Lees AJ, de Silva R: Linkage disequilibrium fine mapping and haplotype association analysis of the tau gene in progressive supranuclear palsy and corticobasal degeneration. J Med Genet 2005;42:837-846. 
$>175$ Rodriguez-Rodriguez P, Sandebring-Matton A, Merino-Serrais P, Parrado-Fernandez C, Rabano A, Winblad B, Avila J, Ferrer I, Cedazo-Minguez A: Tau hyperphosphorylation induces oligomeric insulin accumulation and insulin resistance in neurons. Brain 2017;140:3269-3285.

176 Santacruz K, Lewis J, Spires T, Paulson J, Kotilinek L, Ingelsson M, Guimaraes A, DeTure M, Ramsden M, McGowan E, Forster C, Yue M, Orne J, Janus C, Mariash A, Kuskowski M, Hyman B, Hutton M, Ashe KH: Tau suppression in a neurodegenerative mouse model improves memory function. Science 2005;309:476-481.

$>177$ Sydow A, Van der Jeugd A, Zheng F, Ahmed T, Balschun D, Petrova O, Drexler D, Zhou L, Rune G, Mandelkow E, D’Hooge R, Alzheimer C, Mandelkow EM: Tau-induced defects in synaptic plasticity, learning, and memory are reversible in transgenic mice after switching off the toxic Tau mutant. J Neurosci 2011;31:2511-2525.

-178 Puzzo D, Piacentini R, Fa M, Gulisano W, Li Puma DD, Staniszewski A, Zhang H, Tropea MR, Cocco S, Palmeri A, Fraser P, D’Adamio L, Grassi C: LTP and memory impairment caused by extracellular Abeta and Tau oligomers is APP-dependent. Elife 2017;6:pii: e26991.

179 Kimura T, Whitcomb DJ, Jo J, Regan P, Piers T, Heo S, Brown C, Hashikawa T, Murayama M, Seok H, Sotiropoulos I, Kim E, Collingridge GL, Takashima A, Cho K: Microtubule-associated protein tau is essential for long-term depression in the hippocampus. Philos Trans R Soc Lond B Biol Sci 2014; 369:20130144.

180 Ahmed T, Blum D, Burnouf S, Demeyer D, Buee-Scherrer V, D'Hooge R, Buee L, Balschun D: Rescue of impaired late-phase long-term depression in a tau transgenic mouse model. Neurobiol Aging 2015;36: 730-739.

-181 Ma QL, Zuo X, Yang F, Ubeda OJ, Gant DJ, Alaverdyan M, Kiosea NC, Nazari S, Chen PP, Nothias F, Chan P, Teng E, Frautschy SA, Cole GM: Loss of MAP function leads to hippocampal synapse loss and deficits in the Morris Water Maze with aging. J Neurosci 2014;34:7124-7136.

-182 Ahmed T, Van der Jeugd A, Blum D, Galas MC, D’Hooge R, Buee L, Balschun D: Cognition and hippocampal synaptic plasticity in mice with a homozygous tau deletion. Neurobiol Aging 2014;35:2474-2478.

-183 El Khoury NB, Gratuze M, Papon MA, Bretteville A, Planel E: Insulin dysfunction and Tau pathology. Front Cell Neurosci 2014;8:22.

184 Cheng CM, Tseng V, Wang J, Wang D, Matyakhina L, Bondy CA: Tau is hyperphosphorylated in the insulin-like growth factorI null brain. Endocrinology 2005; 146:50865091.
185 Freude S, Plum L, Schnitker J, Leeser U, Udelhoven M, Krone W, Bruning JC, Schubert M: Peripheral hyperinsulinemia promotes tau phosphorylation in vivo. Diabetes 2005;54:3343-3348.

186 Hong M, Lee VM: Insulin and insulin-like growth factor-1 regulate tau phosphorylation in cultured human neurons. J Biol Chem 1997;272:19547-19553.

187 Lesort M, Johnson GV: Insulin-like growth factor-1 and insulin mediate transient siteselective increases in tau phosphorylation in primary cortical neurons. Neuroscience 2000;99:305-316.

-188 Schubert M, Brazil DP, Burks DJ, Kushner JA, Ye J, Flint CL, Farhang-Fallah J, Dikkes P, Warot XM, Rio C, Corfas G, White MF: Insulin receptor substrate-2 deficiency impairs brain growth and promotes tau phosphorylation. J Neurosci 2003;23:7084-7092.

189 Schechter R, Beju D, Miller KE: The effect of insulin deficiency on tau and neurofilament in the insulin knockout mouse. Biochem Biophys Res Commun 2005;334:979-986.

190 Schubert M, Gautam D, Surjo D, Ueki K, Baudler S, Schubert D, Kondo T, Alber J, Galldiks N, Kustermann E, Arndt S, Jacobs AH, Krone W, Kahn CR, Bruning JC: Role for neuronal insulin resistance in neurodegenerative diseases. Proc Natl Acad Sci USA 2004; 101:3100-3105.

191 Gong CX, Shaikh S, Wang JZ, Zaidi T, Grundke-Iqbal I, Iqbal K: Phosphatase activity toward abnormally phosphorylated tau: decrease in Alzheimer disease brain. J Neurochem 1995;65:732-738.

192 Tanimukai H, Grundke-Iqbal I, Iqbal K: Upregulation of inhibitors of protein phosphatase-2A in Alzheimer's disease. Am J Pathol 2005; 166:1761-1771.

193 Chen S, Li B, Grundke-Iqbal I, Iqbal K: I1PP2A affects tau phosphorylation via association with the catalytic subunit of protein phosphatase 2A. J Biol Chem 2008;283: 10513-10521.

194 Gong CX, Iqbal K: Hyperphosphorylation of microtubule-associated protein tau: a promising therapeutic target for Alzheimer disease. Curr Med Chem 2008;15:2321-2328.

195 Iqbal K, Liu F, Gong CX, Alonso Adel C, Grundke-Iqbal I: Mechanisms of tau-induced neurodegeneration. Acta Neuropathol 2009;118:53-69.

196 Gong CX, Singh TJ, Grundke-Iqbal I, Iqbal $\mathrm{K}$ : Phosphoprotein phosphatase activities in Alzheimer disease brain. J Neurochem 1993; 61:921-927.

197 Chung SH: Aberrant phosphorylation in the pathogenesis of Alzheimer's disease. BMB Rep 2009;42:467-474.

198 Trojanowski JQ, Lee VM: Phosphorylation of paired helical filament tau in Alzheimer's disease neurofibrillary lesions: focusing on phosphatases. FASEB J 1995;9:1570-1576.
199 Domise M, Didier S, Marinangeli C, Zhao H, Chandakkar P, Buee L, Viollet B, Davies P, Marambaud P, Vingtdeux V: AMP-activated protein kinase modulates tau phosphorylation and tau pathology in vivo. Sci Rep 2016;6:26758.

200 Vintem AP, Henriques AG, da Cruz ESOA, da Cruz ESEF: PP1 inhibition by Abeta peptide as a potential pathological mechanism in Alzheimer's disease. Neurotoxicol Teratol 2009;31:85-88.

201 Zhu X, Raina AK, Rottkamp CA, Aliev G, Perry G, Boux H, Smith MA: Activation and redistribution of c-jun $\mathrm{N}$-terminal kinase/ stress activated protein kinase in degenerating neurons in Alzheimer's disease. J Neurochem 2001;76:435-441.

202 Ploia C, Antoniou X, Sclip A, Grande V, Cardinetti D, Colombo A, Canu N, Benussi L, Ghidoni R, Forloni G, Borsello T: JNK plays a key role in tau hyperphosphorylation in Alzheimer's disease models. J Alzheimers Dis 2011;26:315-329.

203 Perry G, Roder H, Nunomura A, Takeda A, Friedlich AL, Zhu X, Raina AK, Holbrook N, Siedlak SL, Harris PL, Smith MA: Activation of neuronal extracellular receptor kinase (ERK) in Alzheimer disease links oxidative stress to abnormal phosphorylation. Neuroreport 1999; 10:2411-2415.

204 Kim B, Backus C, Oh S, Hayes JM, Feldman EL: Increased tau phosphorylation and cleavage in mouse models of type 1 and type 2 diabetes. Endocrinology 2009;150:5294-5301.

205 Kim B, Backus C, Oh S, Feldman EL: Hyperglycemia-induced tau cleavage in vitro and in vivo: a possible link between diabetes and Alzheimer's disease. J Alzheimers Dis 2013; 34:727-739.

206 Takalo M, Haapasalo A, Martiskainen H, Kurkinen KM, Koivisto H, Miettinen P, Khandelwal VK, Kemppainen S, Kaminska D, Makinen P, Leinonen V, Pihlajamaki J, Soininen H, Laakso M, Tanila H, Hiltunen M: High-fat diet increases tau expression in the brain of T2DM and AD mice independently of peripheral metabolic status. J Nutr Biochem 2014;25:634-641.

207 Akiyama H, Barger S, Barnum S, Bradt B, et al: Inflammation and Alzheimer's disease. Neurobiol Aging 2000;21:383-421.

208 Prokop S, Miller KR, Heppner FL: Microglia actions in Alzheimer's disease. Acta Neuropathol 2013;126:461-477.

209 Heneka MT, Kummer MP, Stutz A, Delekate A, Schwartz S, Vieira-Saecker A, Griep A, Axt D, Remus A, Tzeng TC, Gelpi E, Halle A, Korte M, Latz E, Golenbock DT: NLRP3 is activated in Alzheimer's disease and contributes to pathology in APP/PS1 mice. Nature 2013;493:674-678.

210 Yoshiyama Y, Higuchi M, Zhang B, Huang SM, Iwata N, Saido TC, Maeda J, Suhara T, Trojanowski JQ, Lee VM: Synapse loss and microglial activation precede tangles in a P301S tauopathy mouse model. Neuron 2007;53:337-351. 
-211 Laurent C, Dorothee G, Hunot S, Martin E, Monnet Y, Duchamp M, Dong Y, Legeron FP, Leboucher A, Burnouf S, Faivre E, Carvalho K, Caillierez R, Zommer N, Demeyer D, Jouy N, Sazdovitch V, Schraen-Maschke S, Delarasse C, Buee L, Blum D: Hippocampal T cell infiltration promotes neuroinflammation and cognitive decline in a mouse model of tauopathy. Brain 2017;140:184200.

-212 Fernandez-Botran R, Ahmed Z, Crespo FA, Gatenbee C, Gonzalez J, Dickson DW, Litvan I: Cytokine expression and microglial activation in progressive supranuclear palsy. Parkinsonism Relat Disord 2011;17:683688.

213 Kitazawa M, Oddo S, Yamasaki TR, Green KN, LaFerla FM: Lipopolysaccharide-induced inflammation exacerbates tau pathology by a cyclin-dependent kinase 5-mediated pathway in a transgenic model of Alzheimer's disease. J Neurosci 2005;25: 8843-8853.

214 Lee DC, Rizer J, Selenica ML, Reid P, Kraft C, Johnson A, Blair L, Gordon MN, Dickey CA, Morgan D: LPS- induced inflammation exacerbates phospho-tau pathology in rTg4510 mice. J Neuroinflamm 2010;7:56.

215 Ojo JO, Mouzon B, Greenberg MB, Bachmeier C, Mullan M, Crawford F: Repetitive mild traumatic brain injury augments tau pathology and glial activation in aged hTau mice. J Neuropathol Exp Neurol 2013;72: 137-151.
216 Shabab T, Khanabdali R, Moghadamtousi SZ, Kadir HA, Mohan G: Neuroinflammation pathways: a general review. Int J Neurosci 2017;127:624-633.

217 Metcalfe MJ, Figueiredo-Pereira ME: Relationship between tau pathology and neuroinflammation in Alzheimer's disease. Mt Sinai J Med 2010;77:50-58.

218 Leyns CEG, Holtzman DM: Glial contributions to neurodegeneration in tauopathies. Mol Neurodegener 2017;12:50.

219 Hotamisligil GS, Shargill NS, Spiegelman BM: Adipose expression of tumor necrosis factor-alpha: direct role in obesity-linked insulin resistance. Science 1993;259:87-91.

220 Bomfim TR, Forny-Germano L, Sathler LB, Brito-Moreira J, Houzel JC, Decker H, Silverman MA, Kazi H, Melo HM, McClean PL, Holscher C, Arnold SE, Talbot K, Klein WL, Munoz DP, Ferreira ST, De Felice FG: An anti-diabetes agent protects the mouse brain from defective insulin signaling caused by Alzheimer's disease-associated Abeta oligomers. J Clin Invest 2012;122:13391353.

221 Vieira MN, Lyra ESNM, Ferreira ST, De Felice FG: Protein tyrosine phosphatase 1B (PTP1B): a potential target for Alzheimer's therapy? Front Aging Neurosci 2017;9:7.

222 McClean PL, Parthsarathy V, Faivre E, Holscher C: The diabetes drug liraglutide prevents degenerative processes in a mouse model of Alzheimer's disease. J Neurosci 2011;31:6587-6594.
223 Gejl M, Gjedde A, Egefjord L, Moller A, Hansen SB, Vang K, Rodell A, Braendgaard H, Gottrup H, Schacht A, Moller N, Brock B, Rungby J: In Alzheimer's disease, 6-month treatment with GLP-1 analog prevents decline of brain glucose metabolism: randomized, placebo-controlled, double-blind clinical trial. Front Aging Neurosci 2016;8:108.

224 Reger MA, Watson GS, Green PS, Wilkinson CW, Baker LD, Cholerton B, Fishel MA, Plymate SR, Breitner JC, DeGroodt W, Mehta $\mathrm{P}$, Craft $\mathrm{S}$ : Intranasal insulin improves cognition and modulates beta-amyloid in early AD. Neurology 2008;70:440-448.

225 Craft S, Baker LD, Montine TJ, Minoshima S, Watson GS, Claxton A, Arbuckle M, Callaghan M, Tsai E, Plymate SR, Green PS, Leverenz J, Cross D, Gerton B: Intranasal insulin therapy for Alzheimer disease and amnestic mild cognitive impairment: a pilot clinical trial. Arch Neurol 2012;69:29-38.

226 Yanamandra K, Jiang H, Mahan TE, Maloney SE, Wozniak DF, Diamond MI, Holtzman DM: Anti-tau antibody reduces insoluble tau and decreases brain atrophy. Ann Clin Transl Neurol 2015;2:278-288.

227 Yanamandra K, Kfoury N, Jiang H, Mahan TE, Ma S, Maloney SE, Wozniak DF, Diamond MI, Holtzman DM: Anti-tau antibodies that block tau aggregate seeding in vitro markedly decrease pathology and improve cognition in vivo. Neuron 2013;80:402-414 